\title{
Distance learning courses in developing future music teachers' instrumental performance competence
}

\author{
Liudmyla H. Havrilova ${ }^{1[0000-0003-1814-5323]}$, \\ Olena Ye. Ishutina ${ }^{1[0000-0002-7801-4205]}$, \\ Valentyna V. Zamorotska ${ }^{1[0000-0002-8997-114 X]}$ and \\ Darja A. Kassim ${ }^{2}$
}

1 Donbas State Pedagogical University, 19, General Batiouk Str., Sloviansk, 84116, Ukraine

${ }^{2}$ Kryvyi Rih Metallurgical Institute of the National Metallurgical Academy of Ukraine, 5, Stepana Tilhy Str., Kryvyi Rih, 50006, Ukraine \{havrilovalg, olenaishutina, zamorotskavalentyna\}@gmail.com

\begin{abstract}
The scientific and methodological background of creation and development of the distance learning courses for the future music teachers is substantiated. The components and structure of future music teachers' instrumental performance competence are defined; the content of the course is revealed. The materials are based on the authors' teaching experience within the distance learning course "Basic Musical Instrument (Piano)". The main blocks of the distance course design and development are considered among them to be theoretical, practical, individual work, and control blocks. The specificity of distance learning methods in the future music teachers' instrumental and performance training is substantiated and three main methods are distinguished. The method of involving information and communication technologies, including multimedia; project method, and features of knowledge and skills controlling are elaborated. The results of implementation and experimental research of using distance learning courses for developing future music teachers' instrumental performance competence are described. The influence of different methods use on students' success is explored.
\end{abstract}

Keywords: distance learning course, instrumental performance competence, method, ICT, project, test.

\section{Introduction}

One of the characteristic features of contemporary artistic education is its updating in accordance with the requirements of the information space, which is now actively formed within the university information and communication educational environment. A typical phenomenon of artistic education is developing and active implementing of electronic 
educational resources, using the information and multimedia sources, electronic textbooks and manuals, educational and methodical software tools, etc. Gradually, the distance learning tools are also involved in artistic education, and distance learning courses are being developed so that future music teachers can study historical and theoretical, and methodological artistic disciplines. The search for new forms and methods of teaching different types of art, effective in the context of distance education, is relevant for contemporary artistic pedagogy.

\section{Literature review and problem statement}

Informatization of the artistic component of the future music teachers' professional training has become an integral part of the educational process, as it is proved by numerous scientific and pedagogical studies of domestic and foreign scholars (Jacques Arveiller [1], Richard Ashley [14], Natalia V. Belousova [2], Nataliia D. Bieliavina [3], Olena A. Chaikovska [4], Rocio Chao-Fernandez [5], Irina B. Gorbunova [6], Ihor A. Haidenko [7], Andreas Kameris [24], Aleksandr V. Kharuto [9], Igor M. Krasilnikov [11], Aleksei V. Krasnoskulov [12], Nadiia V. Novikova [15], John Michael Ortner [16], Sergei P. Polozov [17], Oleksandr M. Rybnikov [19], Jonathan Savage [21], Galina R. Taraeva [22], Larysa I. Varnavska [23], Irina V.Zabolotskaia [25] and others). Scientists emphasize the importance of using ICT in music education for its transformation into a highly artistic and high-tech process. New software tools, which flexibly combine pedagogical tools of traditional music education and the possibilities of ICT, are actively developed and allow using of the musical computer as a professional tool for a future specialist.

The beginning of the $21^{\text {st }}$ century has been marked by the development and widespread use of computer programs and multimedia for music education: Theano Koutsoupidou develops practical tips for using online distance learning tools in teaching music [10]. Nathan B. Kruse, Steven C. Harlos, Russell M. Callahan and Michelle L. Herring present their experience in Skype music lessons in the academy [13]. J. Savage, the author of several projects on the music education of children by ICT tools, develops new approaches to implementing the computer technologies, taking into account the curriculum, the educational goal, and effective management of the educational process [20, 21]. Rocio Chao-Fernandez, Sara Román-García and Aurelio Chao-Fernandez offer different strategies for learning music by the use of ICT in the context of the music education methodology at secondary school [5]. 
The design, development, implementation of distance learning courses in the field of artistic education, and their support with electronic educational resources are left out in the researches of the modern scholars. It is known that there are some distance learning courses on music and art in the educational environments of the faculties of culture and arts in Ukraine ("History of Music", "Fundamentals of Musical Composition in Choreography", "Relevant Issues of Contemporary Musical Performance", "Modern Ukrainian Music" are offered to students of the National Academy of Managerial Staff of Culture and Arts; distance learning courses "Polyphony", "Vocal", "Methods of Music Education" and some others are introduced into the future music teachers' professional training at the National Pedagogical Dragomanov University). However, the scientific understanding of using the distance learning elements or creating distance learning courses for the disciplines of the artistic educational industry has only just begun to develop in Ukraine. Liudmyla H. Havrilova presents her experience of introducing distance learning courses into the future primary school teachers' artistic training on the example of the distance learning courses "History of musical art of Ukraine" and "Multimedia technologies in artistic education". The author analyses the peculiarities of creating electronic educational resources, multimedia textbooks and manuals on the history of musical art and their systematic involvement in the e-training of future music teachers [8].

\section{The aim and objectives of the study}

The main purpose of the article is to consider the experience of designing and applying distance courses while the students' professional instrumental and performance skills are being developed, and to analyse the specific of distance learning methods in the future music teachers' instrumental and performance training as well.

The research described in the article was conducted in the context of the implementation of the research theme of the Primary Education Theory and Practice Department of the Donbas State Pedagogical University "Professionalism of the Teacher: Theoretical and Methodological Aspects" (the state registration number 0115U003313), where the use of distance courses is considered as one of the conditions of increasing the efficiency of the vocational training process for students, and, in particular, future music teachers.

At the preparatory stage of the study, we developed the distance course "Basic Musical Instrument (Piano)" and at the main stage of 
the study its approbation was carried out in the course of future music teachers' vocational training at the Faculty of Primary, Technological and Professional Education of the Donbas State Pedagogical University and the Art Faculty named after A. Avdievskyi of National Pedagogical Dragomanov University. 52 bachelor students of the specialty 013 Primary education (specialization "Music") participated in the experiment. In order to solve the problems of the research, a set of methods was used: theoretical (analysis of scientific and methodological sources on the problems of using distance courses in the vocational performance training of future music teachers, systematization and generalization of the information collected) and empirical (conversations, questionnaires, pedagogical experiment).

\section{Results of the study}

\subsection{Review of the distance course "Basic Musical Instrument (Piano)"}

The educational discipline "Basic Musical Instrument (Piano)" provides the students with individual classes and with the possibility of adjustment and adaptation in accordance with abilities and preliminary musical training. The course is aimed at the further development of pre-acquired instrumental and performance skills and the students' preparation for the use of the musical instrument at the musical art lessons and in the extra-curriculum activities at secondary educational institutions. The distance course "Basic Musical Instrument (Piano)" like the discipline complements naturally the system of future music teachers' professional performance training, implementing the principles of blended learning and contains the following blocks: 1) theoretical; 2) practical; 3) independent work; 4) control.

Among the main tasks of the course "Basic Musical Instrument (Piano)" we distinguish the following:

1. Forming the interest in pedagogical activity and independent work in instrumental and performance training of the future specialists.

2. Creating a professional basis for further independent work of the future music teachers by means of playing a musical instrument.

3. Optimizing of music teacher vocational training in the integrated unity of musical and performance and pedagogical components.

4. Accumulating the musical repertoire for various forms of educational and extracurricular activities in school and cultural and educational institutions. 
5. Developing the readiness to solve the problems of selecting and interpreting didactic and expedient samples of national and foreign musical art, taking into account age-related abilities of schoolchildren.

6. Acquiring students' aesthetic tastes and value orientations.

7. Forming the individual performing style of the future musical art teachers.

The expected result of studying the discipline and working in the distance course "Basic Musical Instrument (Piano)" is to develop students' professional instrumental performance competence, which involves fluent playing the musical instrument (piano) and the ability to use it in educational, concert, and performance activities; to acquire the skills of reading music from a sheet, transposition, music selection by ear; to master the methods of teaching musical instruments playing; to develop the ability to organize instrumental music for students at musical lessons and in extracurricular activities. In the structure of the future music teachers' instrumental performance competence, traditionally, we distinguish cognitive, operational, and motivational components.

The content of the course "Basic Musical Instrument (Piano)" is organized in 5 modules, which combine 10 themes:

Module 1. Formation of piano and technical skills, professional accompaniment skills

Theme 1. Development of professional musical skills. Complication of technical tasks for the development of a pianist apparatus. Work on music of great form: a variety of techniques in sound production, dramaturgy of contrasting images.

Theme 2. Mastering the necessary skills for concertmaster's work. Professional accompanying skills, familiarity with the textual features of the classical romance, the specifics of reading from the sheet of solo, ensemble works and works of school repertoire.

\section{Module 2. Piano technique development}

Theme 3. Intonational, dynamic, timbral, and rhythmic function of articulation. Analysis of the characteristic features of the musical composition from the school programme, the definition of the necessary requirements for intonation (articulation, timbre, etc.) and rhythmic difficulties.

Theme 4. Generalization of application formulas. The mastery of the technical perfection of the musical programme by working on certain types of techniques that require systematic rehearsal work. Analysis of the application and the detection of patterns. 


\section{Module 3. The structure of polyphonic technique}

Theme 5. Polyphonic multidimensionality as a property of piano texture. Formation of cantil, flexibility, and naturality of intonation skills. Development of polyphonic hearing: the ability to hear the individual expression of each voice. Rehearsal work on intonation of polyphonic texture.

Theme 6. Development of polyphonic hearing. Concept of polyphony for school repertoire. Improving the skills of performing the song for your own support. Harmonize the melody using improvisation elements.

Module 4. Development of piano performance skills

Theme 7. Development of performance skills in the work of polyphonic works of great shape. Continuation of mastering the skills of polyphonic thinking, polyphonic control, its interaction with performances techniques, various types of polyphonic techniques. Ability to master the drama of the musical image in the works of a great form. Formation of large-scale musical thinking.

Theme 8. Development of stylistic and genre interpreting skills. Ability to use knowledge about the form, character, and dynamics of the piano works development. Understanding the meaning of the timbral colour, realizing the artistic design of each of the works of the program.

Module 5. Competence in the field of musical and pedagogical performance

Theme 9. The mastering of musical works from the school repertoire. Knowledge of the reproduction specifics of piano works of different eras, styles, and genres, taking into account the peculiarities of the students' perception.

Theme 10. Realization of pedagogical and executive plan while performing plays for listening. Ability to combine the melodic line and accompaniment, mastering the skills of joint playing music. Ability to perform musical works for listening perfectly, technically, and artistically.

The course "Basic Musical Instrument (Piano)" is preceded by the information block containing general information about the course, a forum for communication with the students, and a glossary for the course providing basic concepts and their interpretation. There are the tasks for creative projects, recommendations for the conclusion of an e-portfolio, tentative repertoire and a list of recommended literature available for downloading (Fig. 1).

The theoretical block of the course aims at forming and developing the cognitive component of the future music teachers' instrumental and performance competence and contains the text materials of lectures 
accompanied with multimedia presentations, charts, tables, as well as multimedia content (audio, video fragments, photo materials, reproductions of works of fine arts etc.). The lecture material is presented in a short form and supplemented with the musical compositions for listening (Fig. 2).

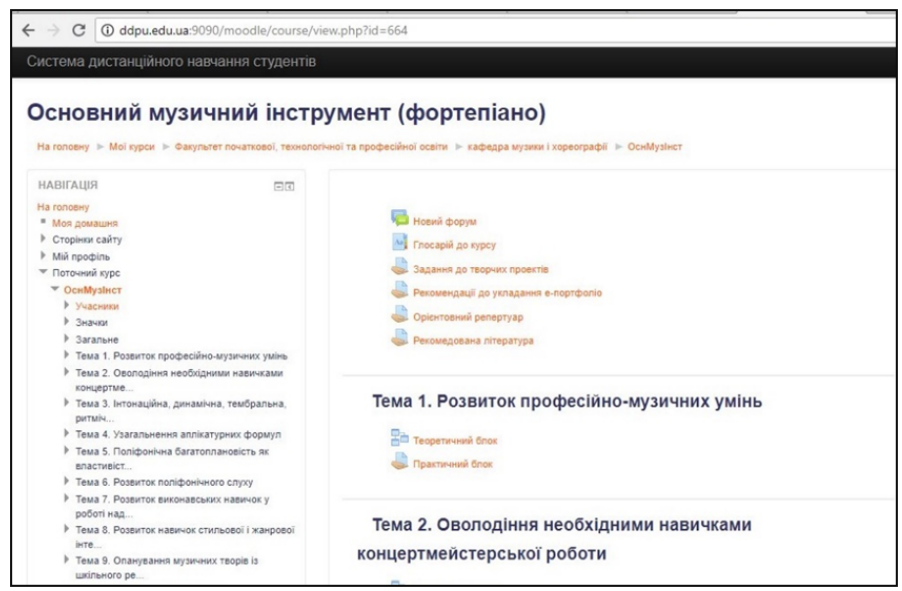

Fig. 1. The information block of the distance learning course "Basic Musical Instrument (Piano)"

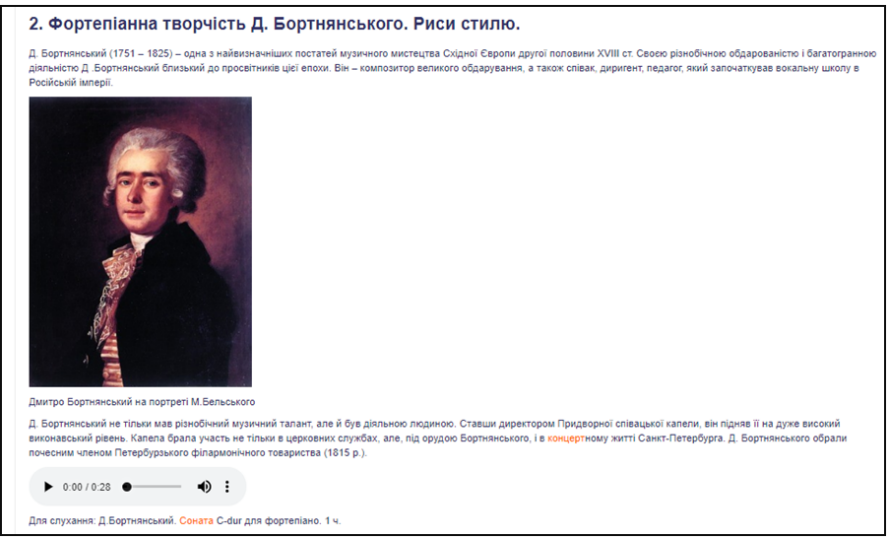

Fig. 2. The fragment of the lecture in the distance learning course "Basic Musical Instrument (Piano)" 
Practical block of the distance learning course "Basic Musical Instrument (Piano)" aims at forming the operational component of the students' instrumental and performance competence and contributes to forming and developing skills and abilities of listening to music, fluent playing the musical instrument, skills of reading music from the sheet, transposition, selection of music on rumour, performance of musical and analytical activity, developing creative musical thinking.

The block of independent work, which contains tasks that require a comprehensive solution through the use of Internet resources, work with multimedia content, its processing, both individually and in group activities, is aimed primarily at the formation of the motivational and value component of the future music teachers' instrumental and performance competence.

The control of musical knowledge and instrumental skills, acquired while mastering the "Basic Musical Instrument (Piano)" distance learning course, takes place in the form of a test (MOODLE's learning environment provides an opportunity to check the knowledge of the theoretical material effectively, as well as mastering the musical compositions of Ukrainian composers by hearing through test tasks of different type, developed in the module "Test") with instant receipt of test results.

\subsection{Specificity of distance learning methods in the future music teachers' instrumental and performance training}

The method of involving information and communication technologies, including multimedia. In order to create a complete performance interpretation, immersion in the content of a musical work requires not only technical perfection but also professional performance skills, the level of which depends directly on a whole complex of musical knowledge, skills, formed aesthetic needs, values orientations, and other personality traits. Therefore, the performer must know and systematize musical forms in their historical development, instrumental studies, and relevant musical literature (biographies of composers, information about musical works), understand the problems of musical aesthetics. The development of artistic trends and creative schools, various aspects of the composer creativity influence spiritual life of society. In addition, musical and instrumental performances involve the use of interdisciplinary connections with history, literature, culture study, and various arts (painting, theatre, cinema, and choreography). Consequently, musical performance interpretive activity

is one of the most diverse kinds of musical activity, which includes a considerable amount of information.

Modern technologies, in particular, multimedia and other computer 
technologies, make it much easier to search for information and help deepen awareness of a particular musical phenomenon due to the other types of information (textual, graphical, static and dynamic visual).

The involving ICTs was in the following areas:

- studying (or profound immersion) the composer's life and work, his individual works on the Internet; studying the scientific articles; listening to audio files; viewing video materials, providing "immersion in an era";

- searching for musical and performance interpretations of the work performed by well-known and little-known pianists in order to analyze the musical performances and compare author's interpretations;

- creating their own verbal interpretations aimed at the certain audience, on the basis of generalization of information from various Internet sources and conducting of thorough analysis of composer and performance expressive means;

- using the resources of musical notices of Internet libraries (Knot's library: http://nlib.org.ua/; Sheet music classical library: http://nlib. narod.ru/; B. Tarakanova Book archive: http://notes.tarakanov.net; D. Roizman's book archive: http://roisman.narod.ru/compnotes.htm and many others);

- involving the electronic context of multimedia encyclopedias and other information publications (New Media Generation, Masterpieces of Music from Encyclopedia, "Sonata: World Culture in the Music of the Mirror of Music" multimedia collection (http: //www.sonata-etc.ru/main.html), KorAx multimedia encyclopedia "Musical Instruments"; "Virtual Museum of Musical Instruments" "Terra Musicalis"; Encyclopedia Music Conservatory from Voyetra Technologies, etc.);

- recording the performance of a musical composition using a video camera or phone for further analysis of the performance interpretation (alone or with the teacher);

- involving visual associations, searching for works of painting and other types of fine art, using of associative ties, artistic analogies to deepen the interpretation of the content of the musical composition.

The method of involving information and communication technologies contributes to the development of certain musical and interpretive performance skills: 
- developing musical thinking autonomy, mastering skills of selfpresentation and communication with different audiences;

- creating auditory model of performing musical work interpretation;

- forming the ability to use the media in training and to evaluate critically their own media activity.

Project method. We determine the algorithm of the creative project activity of the participants in the experimental study for developing the readiness of the future music teacher to perform and interpret the activities in musical and instrumental learning:

- nominating the participants of the artistic and performing project and the choice of the topic;

- setting the problem, purpose and targets of the artistic project;

- defining the type and content of artistic and project activities;

- selecting the methods and tools of implementing artistic and creative project;

- students' independent performing and interpreting activity.

Choosing the project topics, students are offered two types of projects: single-subject project on discipline "Basic Musical Instrument (Piano)" (design and interpretation activities within the repertoire and performance tasks in the classes of musical specialty) and a multi-subject project within the professional disciplines ("Workshop on the school repertoire", "Additional musical instrument", "History of musical styles", "Analysis of musical works", etc.). The specific themes of the projects are agreed with the participants of the experimental study for developing the future music teachers' readiness to perform and interpret the activities in musical and instrumental education. In the information block of the distance learning course, students are offered topics of various content, taking the individual level of project group members and their musical tastes into account.

The projects are carried out in the academic year and are evaluated by the teachers at the stage of both current and final control. Students discuss their projects in the forum and send interim and final reports on project implementation using the module "Task".

Project "Harmony of Music and Painting in the Work of M. Churloniss". To implement the project, a group of students is divided into teams:

- search engineers (main activity is information retrieval: search for information about the life and work of the famous Lithuanian composer and artist on the Internet, as well as search for piano 
pieces - Fugue $\mathrm{C}$ minor, Preludes in the minor, Preludes in $\mathrm{C}$ major in the performance of various pianists and paintings M. Churloniss "Fuga", "Signs of the Zodiac", etc.);

- art critics (main activity is musical and analytical: musicology, musical-pedagogical and interpretive analysis of the certain works of M. Churloniss for piano; the creation of analytical schemes; aesthetic and stylistic analysis of paintings and analysis of the principle embodiment of musical expressiveness in the artist's paintings).

The final stage of the project "Harmony of Music and Painting in the Work of M. Churloniss" is an executable interpretation of three musical works by the composer, and they are accompanied with a multimedia slide show, which presents the author's pictures that are closely associated with the musical text. The performers' laconic and accurate comments go along with the sound of music.

The project "Pictures at an exhibition" by M. Mussorgsky: implementing the principles of integrating musical and pictorial. The purpose of this project is to direct the students' interpretation to the search for adequate sonorities, colours and shades, and the departure from the traditional canons of interpreting the famous piano cycle by M. Mussorgsky.

For this purpose, we nominate the project teams:

- search engineers (main activity - information retrieval: searching for information about the life and work of M. Mussorgsky and his friend V. Hartman on the Internet, searching for the most vivid piano and orchestral interpretations of the cycle "Pictures from the exhibition", as well as searching for reproductions of works, inspired the composer to create music);

- art critics (main activities - musical and analytical: musicology analysis of individual works of the cycle, as well as analysis and evaluation of performance interpretations found);

- IT specialists (the main type of the activity is creating the informational multimedia support for the interpretive interpretations of M. Mussorgsky's piano cycle, their visualization by means of computer technologies);

- performers-interpreters (main activity - interpretative: musical performance with brief comments on the content, means of expressiveness and musical form).

The project is implemented in the form of a concert performance by students-performers who offer their own interpretations of famous works 
by M. Mussorgsky's "Walk", "Two Jews", "The Chants' Ballet", "Dwarf", "Baba Yaha". Their play is accompanied with a brief poetic story (art critics choose poetry lines) and a visual series (listeners can at the same time listen to music and review the works by V. Hartmann, inspired by the composer). The main content accent of performing interpretation is made not on the "figurative" aspect of works, but on the embodiment of feelings and emotional essence of events, that is, their "expressive" reproduction.

Specific features of controlling the knowledge and skills, acquired during the study of the course "Basic Musical Instrument (Piano)". In order to test the formation of the key knowledge gained while studying the distance course "Basic Musical Instrument (Piano)", it is enough to conduct an ordinary test in the MOODLE learning environment using different test types (Fig. 3).

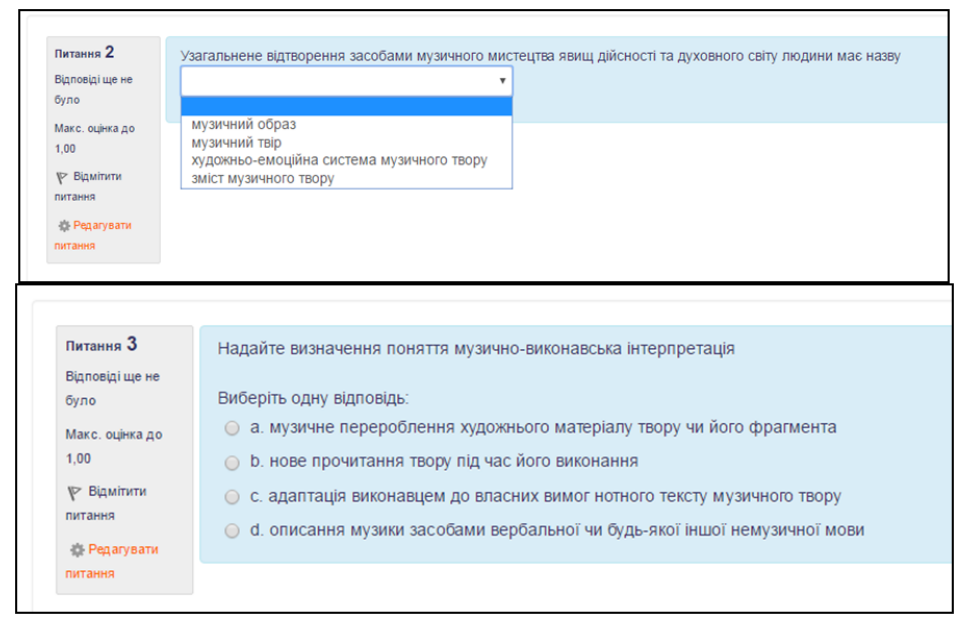

Fig. 3. The examples of the question in the test

The verification of specific musical knowledge, as well as the formation of special skills to percept music, the development of music listening skills, the recognition of musical works while listening requires the musical quiz conducting (recognition of works with the definition of their authors, parts or a specific topic of the great work). The quiz is developed using the possibilities of the service "Test" of the learning environment MOODLE in two versions:

- the task of the closed form (listen to the piece of music and choose the correct answer among the proposed ones); 
- the task of the opened form (the "essay" question type: after listening to the fragments of the musical composition, you must enter the answer to the designated place, indicating the author, the exact title of the work and section, the act of the opera, part of the symphony or topic, etc.) (Fig. 4).

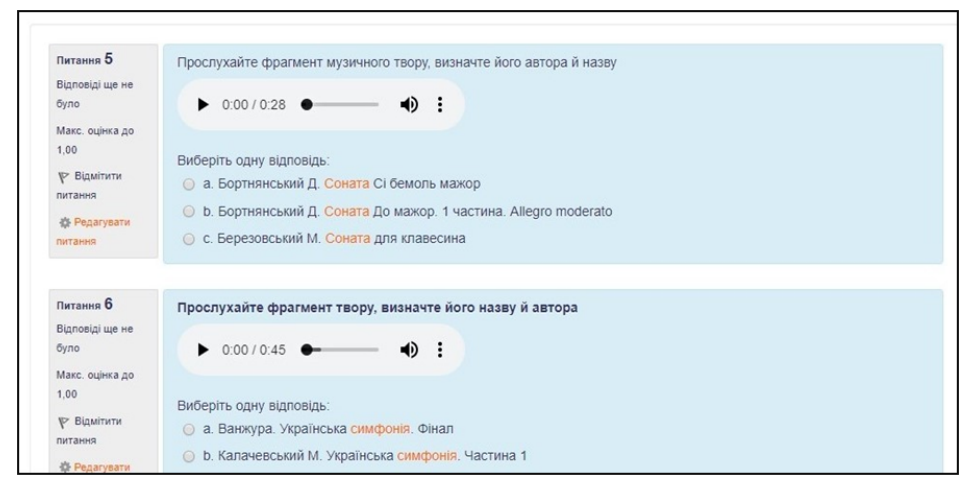

Fig. 4. Questions of the musical quiz (service "Test" of the MOODLE)

The practice of using e-tests as a tool of control proves that they are more appropriate for monitoring the cognitive component of the future music teachers' instrumental and performance competence than the operational and motivational ones.

4.3 Analysis of the efficiency of the distance course implementing into the future music teachers' instrumental and performance training

In the end of the academic year, the evaluation of the distance course efficiency has been held. Respondents were separated into two groups: experimental group (27 students) and control group (25 students). The experimental group worked in the distance course "Basic Musical Instrument (Piano)" in addition to the classes. The students of the control group were involved in studying according to traditional methods and techniques. They attended individual and group classes on the basic musical instrument, ensemble and concertmaster class, and others, which corresponded to the typical curriculum. Classes with students of control groups were conducted using traditional methods, without the involvement of information and communication technologies and distance learning.

The level of the motivational component of the future music teachers' instrumental performance competence was assessed with the interviews. 
The interviews were conducted informally through discussion as a part of observation. The results are presented in the table (Table 1) and demonstrate higher indicators of the students' interest in instrumental and performance work. It was also noticed that student attendance in the experimental group had increased by $12 \%$ compared to the control one.

Table 1. Level of the motivational component of the future music teachers' instrumental performance competence

\begin{tabular}{|l|c|c|c|c|}
\hline \multirow{2}{*}{ Levels } & \multicolumn{2}{|c|}{ Experimental group } & \multicolumn{2}{c|}{ Control group } \\
\cline { 2 - 5 } & Students & $\mathbf{\%}$ & Students & $\mathbf{\%}$ \\
\hline High & 9 & 37 & 6 & 24 \\
\hline Upper middle & 12 & 44 & 9 & 36 \\
\hline Lower middle & 5 & 19 & 8 & 32 \\
\hline Low & 1 & 4 & 2 & 8 \\
\hline
\end{tabular}

In order to assess the cognitive component of the future music teachers' instrumental performance competence, the results of testing, implemented in the virtual learning environment MOODLE, were involved. The results are presented in the table (Table 2) and prove that the pedagogical experiment significantly improved the artistic and professional thesaurus of future teachers and increased the level of students' skills in the field of instrumental and performing interpretations.

Table 2. Level of the cognitive component of the future music teachers' instrumental performance competence

\begin{tabular}{|l|c|c|c|c|}
\hline \multirow{2}{*}{ Levels } & \multicolumn{2}{|c|}{ Experimental group } & \multicolumn{2}{c|}{ Control group } \\
\cline { 2 - 5 } & Students & $\mathbf{\%}$ & Students & $\mathbf{\%}$ \\
\hline High & 10 & 37 & 5 & 20 \\
\hline Upper middle & 13 & 48 & 10 & 40 \\
\hline Lower middle & 4 & 15 & 8 & 32 \\
\hline Low & 0 & 0 & 2 & 8 \\
\hline
\end{tabular}

The level of the operational component of the future music teachers' instrumental performance competence was assessed with the final exam, which involved verbal communication and musical performance. The results are presented in the Table 3 . 
Table 3. Level of the operational component of the future music teachers' instrumental performance competence

\begin{tabular}{|l|c|c|c|c|}
\hline \multirow{2}{*}{ Levels } & \multicolumn{2}{|c|}{ Experimental group } & \multicolumn{2}{c|}{ Control group } \\
\cline { 2 - 5 } & Students & $\mathbf{\%}$ & Students & $\mathbf{\%}$ \\
\hline High & 10 & 37 & 6 & 24 \\
\hline Upper middle & 15 & 44 & 9 & 36 \\
\hline Lower middle & 5 & 19 & 10 & 40 \\
\hline Low & 0 & 0 & 0 & 0 \\
\hline
\end{tabular}

Overall, our results demonstrate a strong effect of implementing the distance learning course "Basic Musical Instrument (Piano)" into future music teachers' vocational training, since the level of each component of the instrumental performance competence has increased in the experiment group.

\section{Conclusion}

Implementation of the distance course "Basic Musical Instrument (Piano)" into the system of future music teacher training at SHEI "Donbas State Pedagogical University" makes it possible to draw conclusions:

1. Students' work in the distance course "Basic Musical Instrument (Piano)" should be combined with the curricular activities, piano playing practice, and direct contact counselling. Therefore, this combination of forms and methods of distance and traditional education represents a blended model [18], rather than purely distance learning. In this mode of work, the teacher begins to fulfil duties of a tutor, who accompanies and directs the instrumental and practical training of students in the e-learning environment and in curricular instructions.

2. In view of the positive results of implementing distance courses in the instrumental and performance training of future music teachers, the prospects of further scientific research are to develop and use new forms and methods of distance learning: scribing, intellectual maps and comics as varieties of modern educational infographics, etc. 


\section{References}

1. Arveiller, J., Bull, H.-L., Roads, C.: Comments on University Instruction in Computer Music Composition. Computer Music Journal 6 (2), 72-78 (1982). doi: 10.2307/3679681

2. Belousova, N. V.: Informatcionnye tekhnologii v protcesse spetcialnoi podgotovki pedagoga-muzykanta (Information technology in the process of special training of a teacher-musician). Dissertation, Moscow City Pedagogical University (2012).

3. Bieliavina, N. D.: Deiaki metodychni problemy vykorystannia novykh kompiuternykh tekhnolohii $\mathrm{v}$ muzychnii osviti (Some methodical problems of the use of new computer technologies in music education). Kultura i mystetstvo v suchasnomu sviti: Naukovi zapysky KDUKiM 1, 195-201 (1998).

4. Chaikovska, O., Aleksandrova, H.: Multymediini tekhnolohii yak chynnyk formuvannia innovatsiinoho navchalnoho seredovyshcha na urokakh muzyky (Multimedia technologies as a factor of formation of innovative educational environment at music lessons). Ridna shkola 3, 66-69 (2013).

5. Chao-Fernandez, R., Román-García, S., Chao-Fernandez, A.: Analysis of the use of ICT through music interactive games as educational strategy. Procedia - Social and Behavioral Sciences 237, 576-580 (2017). doi: $10.1016 /$ j.sbspro.2017.02.109

6. Gorbunova, I. B.: Fenomen muzykalno-kompiuternykh tekhnologii kak novaia obrazovatelnaia tvorcheskaia sreda (The phenomenon of musical computer technologies as a new educational creative medium). Izvestiia Rossiiskogo gosudarstvennogo pedagogicheskogo universiteta im. A. I. Gertcena 9, 123-138 (2004).

7. Haidenko, I. A.: Rol muzychnykh kompiuternykh tekhnolohii u suchasnii kompozytorskii praktytsi (The Role of Computer Technologies in Contemporary Composer Practices). Dissertation, Kharkiv State University of Arts named after I. P. Kotlyarevsky (2005).

8. Havrilova, L. H.: Specifics of the development of distance courses for musical historical disciplines. Information technologies and learning tools 58 (2), 26-37 (2017). doi: 10.33407/itlt.v58i2.1596

9. Kharuto, A.V.: Muzykalnaia informatika: Teoreticheskie osnovy (Musical Informatics: Theoretical Foundations). LKI, Moscow (2009). 
10. Koutsoupidou, T.: Online distance learning and music training: benefits, drawbacks and challenges. Open Learning: The Journal of Open, Distance and e-Learning 29(3), 243-255 (2014). doi: $10.1080 / 02680513.2015 .1011112$

11. Krasilnikov, I. M.: Pedagogika tcifrovykh iskusstv novoe napravlenie razvitiia teorii i praktiki khudozhestvennogo obrazovaniia (Pedagogy of digital arts - new direction of development theory and practice of art education). Pedagogika 5, 56-58 (2012).

12. Krasnoskulov, A.: Kompiuternoe modelirovanie muzykalnoi faktury (Computer simulation of musical texture). In: Muzyka v informatcionnom mire: Nauka. Tvorchestvo. Pedagogika. RGK im. S. V. Rakhmaninova, Rostov-na-Donu (2004).

13. Kruse, N. B., Harlos, S.C., Callahan, R. M., Herring, M. L.: Skype music lessons in the academy: Intersections of music education, applied music and technology. Journal of Music, Technology \& Education 6 (1), 43-60 (2013). doi: 10.1386/jmte.6.1.43_1

14. Lee, K. M., Skoe, E., Kraus, N., Ashley, R.: Neural Transformation of Dissonant Intervals in the Auditory Brainstem. Music Perception: An Interdisciplinary Journal 32 (5), 445-459 (2015). doi: $10.1525 / \mathrm{mp} .2015 .32 .5 .445$

15. Novikova, N. V.: Formuvannia piznavalnoho interesu pidlitkiv na urokakh muzyky zasobamy multymediinykh tekhnolohii (Formation of cognitive interest of teenagers in music lessons by means of multimedia technologies). Dissertation, National Pedagogical Dragomanov University (2011).

16. Ortner, J.M.: The effectiveness of a computer-assisted instruction program in rhythm for secondary school instrumental music students. Dissertation, State University of New York at Buffalo (1990).

17. Polozov, S.: The Issue of Autonomy in Using Computer Information Technologies as a Means of Teaching Music. In: Proceedings of the $9^{\text {th }}$ International Conference on Virtual Learning (ICVL), pp. 194-200. Bucharest University Press, Bucharest (2014).

18. Rashevska, N. V., Semerikov, S. O., Slovak, K. I., Striuk, A. M.: Model kombinovanoho navchannia $u$ vyshchii shkoli Ukrainy (The blended learning model in Ukrainian higher education). In: Sbornik nauchnykh trudov, pp. 54-59. Miskdruk, Kharkiv (2011). 
19. Rybnikov, O.M.: Formuvannia hotovnosti maibutnoho vchytelia muzyky do vykorystannia tsyfrovoho elektronnoho muzychnoho instrumentariiu $\mathrm{u}$ profesiinii diialnosti (Formation of readiness of future music teacher to use digital electronic musical instruments in professional activity). Dissertation, Borys Grinchenko Kyiv University (2013).

20. Savage, J.: Teaching Music with ICT. In: Finney, J., Burnard, P. (eds.) Music Education with Digital Technology. Continuum, London. 142-155 (2010).

21. Savage, J.: Reconstructing Music Education Through ICT. Research in Education 78 (1), 65-77 (2004). doi: 10.7227/RIE.78.6

22. Taraeva, G.R.: Kompiuter i innovatcii v muzykalnoi pedagogike (Computer and innovation in musical pedagogy). Klassika-XXI, Moscow (2007).

23. Varnavska, L. I.: Formuvannia hotovnosti studentiv do vykorystannia kompiuternykh tekhnolohii na urokakh muzyky (Formation of Students' Readiness for Using Computer Technologies at Music Lessons). Pedahohika vyshchoi ta serednoi shkoly 38, 11-15 (2013).

24. Voronov, A. M., Gorbunova, I. B., Kameris, A., Romanenko, L. Yu.: Muzykalno-kompiuternye tekhnologii v shkole tcifrovogo veka (Music and computer technologies at digital age school). Vestnik IrGTU 5 (76), 240-246 (2013).

25. Zabolotskaia, I. V.: Novye informatcionnye tekhnologii v muzykalnom obrazovanii (New information technologies in music education). Dissertation, Herzen State Pedagogical University of Russia (2000). 